Kennesaw State University

DigitalCommons@Kennesaw State University

Faculty Publications

$10-2011$

\title{
The Impact of Prolonged Nomination Contests on Presidential Candidate Evaluations and General Election Vote Choice: The Case of 2008
}

Jeff R. Dewitt

Kennesaw State University, jdewitt@kennesaw.edu

Richard N. Engstrom

Kennesaw State University, rengstro@kennesaw.edu

Follow this and additional works at: https://digitalcommons.kennesaw.edu/facpubs

Part of the American Politics Commons

\section{Recommended Citation}

Dewitt, J. R., \& Engstrom, R. N. (2011). The impact of prolonged nomination contests on presidential candidate evaluations and general election vote choice: The case of 2008. Politics \& Policy, 39(5), 741-759. doi:10.1111/j.1747-1346.2011.00311.x

This Article is brought to you for free and open access by DigitalCommons@Kennesaw State University. It has been accepted for inclusion in Faculty Publications by an authorized administrator of DigitalCommons@Kennesaw State University. For more information, please contact 


\title{
The Impact of Prolonged Nomination Contests on Presidential Candidate
}

\author{
Evaluations and General Election Vote Choice: The Case of 2008
}

\author{
JEFF R. DEWITT \\ Kennesaw State University \\ RICHARD N. ENGSTROM \\ Kennesaw State University
}

The fact that political parties hold competitive nomination contests that require voters to choose among multiple candidates leaves open the possibility that the contest itself could damage the prospects of an eventual nominee. In this study, we employ ANES panel survey data from the 2008 U.S. presidential election to assess the impact of the Democratic Party nomination process on candidate evaluations and general election vote preference. We find evidence that Barack Obama had greater difficulty uniting his party than his Republican counterpart due to the fact that Clinton voters were slow to coalesce around Obama. These supporters failed to report higher levels of favorability until Clinton conceded the race in the summer, while Huckabee and Romney voters were seen rallying to their party's nominee in the spring. In the end, many Clinton primary voters either abstained from voting in November or crossed over to support the Republican nominee.

Keywords: Parties, Elections, Campaigns, Voting Behavior, Public Opinion, Political Parties

El hecho de que los partidos políticos realicen contiendas de nominaciones competitivas que exijan a los votantes elegir entre múltiples candidatos crea la posibilidad de que la contienda en sí misma perjudique las expectativas del candidato ganador. En este estudio, empleamos datos de una encuesta de ANES sobre las elecciones presidenciales del 2008 en los Estados Unidos para determinar el impacto del proceso de nominación presidencial del Partido Demócrata en la evaluación de los candidatos y las preferencias electorales generales. Encontramos evidencia de que Barack Obama tuvo una mayor dificultad unificando su partido que su equivalente Republicano debido a que partidarios de Clinton fueron lentos en sumarse a Obama. Estos partidarios no reportaron altos niveles de apoyo hasta que Clinton confirió la contienda en el verano, mientras que partidarios de Huckabee y Romney se concentraron en el candidato de su partido desde la primavera. Al final, muchos votantes adeptos a Clinton se abstuvieron de votar en noviembre o decidieron apoyar al candidato Republicano. 
In the United States, presidential elections are the second round of a two-stage selection process that begins months earlier with a series of party primary elections and caucuses. During the primary stage, when Democratic and Republican candidates compete for their parties' nominations, an inherent political risk rests in the fact that voters may find it difficult to shift their allegiances to the opponent of their preferred candidate for the general election. Most often, nomination battles are settled by mid-March, which presumably serves to resolve intra-party disputes well in advance of the general election campaign as parties use the remainder of the spring and summer to rally support around the nominee (Mayer and Busch 2003).

However, the 2008 Democratic nomination contest provides a notable exception to the usual pattern (Burden 2009). It did not end quickly and failed to provide the Democrats with a seamless transition to the general election campaign. Indeed, the Barack Obama versus Hillary Clinton race was one of the most contentious primary contests in decades and some wondered whether the discord would extend all the way to November. As one observer noted, "Hillary Rodham Clinton may still have a chance of winning the Democratic nomination. But it's probably smaller than the chance that a continued slugfest will hand the White House to John McCain" (Kristof 2008). Obama did not officially clinch the Democratic nomination until June 3, and it was not until June 7 that Clinton suspended her campaign. Even after the nomination contest was officially wrapped up, questions about Democratic party unity continued to linger (e.g., Tumulty 2009).

In this study, we employ panel survey data from the 2008 U.S. presidential election to assess the impact of the prolonged Democratic Party's nomination process on individuals' candidate evaluations and general election vote preferences. We find evidence that Barack Obama had greater difficulty uniting his party than his Republican counterpart. This was due to 
the fact that many Hillary Clinton primary voters were reluctant to shift their support to Obama, a challenge compounded by the shorter time period the Democratic nominee had to win them over. While it is true that Clinton primary voters were not initially pre-disposed to support Obama - they were only mildly approving of Obama at the start of the year - the shift in their electoral support toward Obama was delayed until the summer, while supporters of John McCain's Republican rivals can be seen rallying around their party's nominee as early as March. Ultimately, the delayed conclusion of the nomination contest led to a less-than-unified Democratic Party. The consequences of this prolonged party disunity are demonstrated in our finding that Clinton primary voters were no more likely to vote for Barack Obama in the general election than to not vote, or to vote for John McCain.

\section{Primaries and General Election Outcomes}

Taken at face value, a hard-fought presidential primary process would seem to be detrimental to that party's chances of winning the general election in November. Numerous studies employing a variety of methodological techniques provide support for that conclusion (Lengle, Owen, and Sonner 1995; Lengle 1980; Kenney and Rice 1984, 1987; Hacker 1965). Atkeson (1998), however, finds that a party's primary generates minimal impact on general election outcomes once crucial contextual factors for each election such as the state of the economy and the popularity of the incumbent president have been considered.

Studies of lower-level elections lend support to the finding that primaries can damage the chances of nominees in the general election. In fact, the most prominent factor in determining success in the general election can also be understood as the factor that determines the level of competition for a primary nomination: incumbency. Incumbents face the fewest challengers for their party's nomination, and are subsequently the most successful category of candidate running 
in general elections (Stone and Maisel 2003; Lazarus 2005; Glaser 2005). An examination of congressional candidates and campaign managers by Ezra (2001) finds that competitive primaries may be especially damaging for certain kinds of candidates. In particular, those with a great deal of "political capital" (experience, name recognition, campaign money, and organization) may suffer from a more heated primary battle. Candidates with little political capital, though, might even profit from the practice, exposure, and legitimacy that a hard fought primary campaign provides.

While conventional academic wisdom holds that competitive primary campaigns bear important electoral implications, we know little about the impact of an extended primary campaign season. The longer the nomination contest drags on, the more time a party must dedicate to resolving intra-party conflict and the less time it may have to dedicate to unifying electoral support around the eventual nominee. Given the uniquely prolonged nomination battle and the abbreviated general electoral calendar in 2008, it is plausible that the nomination contest itself lessened the support the Democratic Party nominee was ultimately able to acquire in November. By tracking voter attitudes over time, we are able to determine how support for candidates pursuing the nomination changed, when those changes took place, and how these dynamics ultimately affected the general election vote.

\section{The 2008 Presidential Election}

The 2008 Democratic nomination contest serves as a useful case study for the theory that prolonged primaries effectively harm a party's presidential nominee. The March 5, 2008 headline, "Clinton wins key primaries, CNN projects; McCain clinches nod," illustrates the contrasting electoral dynamics between the two parties (CNN 2008). If a race that is marked by a heavily contested primary season that lasts until every state has cast its votes shows no effect on 
the nominee's ability to gain supporters and rally voters in November, where could one expect an effect? If prolonged presidential primaries harm party nominees, we would expect the 2008 race to produce a sizeable number of Clinton primary voters who find it difficult to approve of Obama at high levels and movement his way during the general election stage would be hindered by the shorter electoral calendar. Obama's favorability among Democrats would be lower throughout the longer primary campaign while Republicans coalesce around their nominee.

Ultimately, we should see larger numbers of Clinton primary votes either abstaining in November or voting for the Republican, John McCain. Of course, it is overly reductive to conclude that no harm was done to Obama's prospects based simply on the fact that Obama went on to win the general election. It is plausible that the prolonged nomination contest issued a substantial blow, though not a fatal one, to Obama's presidential chances. Perhaps he garnered less support, and fewer votes, than he would have if the transition from nomination to general stages had been more swift and seamless.

Much has already been written about the historic 2008 election. Political science research has examined the impact of racial attitudes on voting decisions (Lewis-Beck, Tien, and Nadeau 2010; Jackman and Vavreck 2010; Piston 2010), the role the war in Iraq played in the outcome (Jacobson 2010), and how partisanship shifts among voters may have worked in favor of the winning candidate (Winneg and Jamieson 2010). Several studies have also explored the impact of the Democratic Party contest on how people voted in the general election. Southwell (2010), for example, examines whether Hillary Clinton supporters were more likely to stay home on Election Day or defect to the Republican candidate rather than cast a ballot for their preferred candidate's intra-party rival. Though Southwell notes that significant numbers of Clinton voters flipped to John McCain in November, she concludes that the nomination battle was probably not 
to blame. ${ }^{1}$ Similarly, Henderson et al. (2010) examine whether or not "sour grapes" left over from the primary prompted many Clinton voters to defect to McCain. They find that ideology and policy preferences were actually more important factors than any negative fallout from the divisive primary process.

Studies such as those mentioned above explore the ultimate electoral damage that primaries can cause to nominees based on whether or not voters shift their support to the chief partisan rivals of most preferred candidates. They assume that support for a particular party candidate also reflects opposition to the alternatives. ${ }^{2}$ This may not be the case. Rather than assume that voters who prefer candidate A would prefer that candidate B not be elected, we acknowledge that primary voters and caucus participants may be expressing their preferences for one candidate among several candidates (in both parties) whom they could potentially support at any point during the campaign season. As such, in this study, we explore the longitudinal trends in levels of support for both the Democratic and Republican nominees independently and also relative to one another among various groupings of primary voters. In doing so, we are better able to illustrate linkages between presidential primaries and the dynamic nature of candidate evaluations over the course of an entire election season.

Moreover, it is important to note that predicting a change in political behavior among partisan voters is a very "high bar." Primary voters are some of the most reliably active, partisan electoral participants (Norrander 1986). It is also well established that presidential candidates tend to pursue a self-interest-maximizing, "securing the base first" general election strategy

\footnotetext{
${ }^{1}$ Interestingly, Southwell (2010) finds that John Edwards voters were statistically similar to Clinton voters in their tendency to support John McCain, which suggests that the consequences of prolonged primary contests do not necessarily build resentment over an extended period of time.

${ }^{2}$ Numerous analysts highlighted the seemingly vast differences between Clinton supporters and Obama supporters (see e.g., Newport 2008; Sussman 2008).
} 
(Peress 2010), often taking these voters for granted as the two parties converge around the median voter after nominations are achieved. Other scholarship has suggested a "neo-Downsian" electoral trend, characterized by partisan divergence (Grofman 2005), whereby political candidates, especially the 2008 nominees, are prone to assume positions "closer to their median voter in their respective parties than to the national voter median" (Jesse 2010, 205). As such, for this group of voters to alter its typically firm general election support would be extremely noteworthy and the circumstances leading to such changes are worth investigation. Given this theoretical context, we expect to find that Barack Obama had greater difficulty uniting his party than his Republican counterpart. Our working hypotheses are twofold. First, due to the prolonged Democratic Party primary, Clinton voters will be slow to coalesce around Obama while Huckabee and Romney voters will be seen rallying to their party's nominee in the spring. Second, in the end, many Clinton primary voters will either abstain from voting in November or cross over to support the Republican nominee.

\section{Data and Methods}

Most academic investigations of presidential primaries have relied on Election Day vote tallies and aggregate polling data. Distributional measures and independent cross-sectional surveys are employed, with results interpreted to reveal the broad level impact of contentious nomination contests. This study, in contrast, uses 2008 panel data compiled by the American National Election Study to provide a more focused presentation of the electoral dynamics embedded within the context of a single election year. Panel data are especially useful in that they provide us with the opportunity to study how a consistent set of respondents changed 
attitudinally and behaviorally over time. ${ }^{3}$ In that respect, our methodological model mirrors Hillygus's examination of individual-level dynamics during the 2000 presidential election.

The 2008 dataset, in particular, includes a representative sample of respondents who answered questions at multiple points over the course of the primary and general election seasons. ${ }^{4}$ Our principal focus is on seven-point candidate favorability scores across five panel waves-January, February, June, September, and October-in addition to a post-election candidate preference variable. We present descriptive analyses and regression models which highlight longitudinal trends in electoral judgments regarding the party nominees (Barack Obama and John McCain) among voters who supported them and their principal rivals (Hillary Clinton, Mike Huckabee and Mitt Romney) in the presidential primaries. ${ }^{5}$

Fallout from a primary season may produce voters who are more or less supportive of the nominee at various points during the campaign and may either refrain from participating in the November general election, as a reflection of "abstention due to alienation" (Brody and Page 1973; Adams and Merrill 2003), or even cross over to cast ballots for the opposing party candidate as a "sour grapes" protest against the nominee (see Henderson et al. 2010). Analyses presented here examine support for Obama and McCain in light of these scenarios. We assess whether or not changes in the level of favorability for Obama are related to voting for Hillary Clinton in the primaries, placing special emphasis on the extended nature of Democratic

\footnotetext{
${ }^{3}$ See Bartels (1999) for a summary of the advantages of panel data and Miller (1999) for a discussion of the utility of panels for clarifying judgmental relationships.

${ }^{4}$ The 2008-2009 ANES employed a telephone recruited internet panel which answered political questions in January, February, June, September, October, and November 2008. The overall response rate was 42 percent. Panel weights are used in order to help correct for panel attrition. Our working dataset, which does not include the second cohort added in September, is comprised of 1623 cases. For more information on the dataset, please see ANES documentation at http://www.electionstudies.org/studypages/2008_2009panel/anes2008_2009panel.htm.

${ }^{5}$ Hillary Clinton voters are represented in a single, stand-alone category. Huckabee and Romney voters are merged into a common category of Republican contenders.
} 
nomination campaign. McCain's numbers serve as a useful baseline for comparison purposes since the Republican nomination contest followed a relatively conventional form.

\section{Findings}

If Hillary Clinton's decision to continue campaigning against Barack Obama negatively impacted support for Barack Obama, and hindered his ability to unify the party, we should see the favorability scores of Obama remain low, or even decrease, over the course of the prolonged primary contest. Figure 1 tracks the average panel respondent placement of Barack Obama on a seven-point favorability scale. Indeed, during the first six months of 2008 , the entire course of the protracted nomination contest, Obama's scores remained almost perfectly flat among those who preferred Clinton, increasing only .12 (from 4.49 in January to 4.61 in June). While his favorables with this group finally began inching upward after the Democratic contest concluded with Clinton's concession and endorsement in early June and her August 28 DNC convention speech in which she proclaimed that she was a "proud supporter of Barack Obama" (from 4.61 in June to 4.97 in September), they never moved much beyond the score of five.

\section{[INSERT FIGURE 1 ABOUT HERE]}

Figure 2 displays longitudinal trends for John McCain, which are quite different than those for his Democratic counterpart. Initially, McCain's favorability scores among Mike Huckabee and Mitt Romney voters hovered around his overall score (4.69 versus 4.63). After his two rivals' concessions and endorsements, ${ }^{6}$ however, support for McCain increased for this group, even as the general public and McCain primary voters grew less favorable. Clearly, by June, Romney and Huckabee voters had begun rallying around the party's nominee, as would seem to be the conventional track. By September, their approval of McCain had improved by

\footnotetext{
${ }^{6}$ John McCain effectively claimed the Republican nomination with Romney's withdrawal from the race on February 7, 2008. Huckabee dropped out on March 4.
} 
nearly a full point, to 5.59 on the seven-point scale. This steady positive movement on the part of Republican primary voters indicates that McCain wielded an impressive electoral advantage in his effort to unify the GOP, especially considering that Clinton primary voters were slow to coalesce around Obama.

\section{[INSERT FIGURE 2 ABOUT HERE]}

In Tables 1 and 2, we present results from a series of OLS regression equations that further explore the impact of primary candidate preference and the prolonged Democratic nomination contest on electoral support over the course of the 2008 presidential campaign. The dependent variables are favorability scores for the two party nominees at each of the five panel wave data points. As indicated in Table 1, being a Clinton primary voter significantly decreased support for of Obama in January $(b=-1.06)$ and February $(b=-.51)$, after controlling for party and the favorability score provided by the respondent in the previous wave. In fact, at no time did supporting Clinton produce significantly higher favorability rating for Obama. This was true even after her concession, endorsement, and convention speech, which strongly encouraged party unity.

To further confirm the proposition that Clinton primary voters were slow to shift their support to Obama, we ran an additional OLS regression model in which we used Obama favorability at each given wave as the dependent variable. In addition to controls for party affiliation and a lagged variable representing the respondent's Obama favorability score in the previous wave, we introduced a dummy variable to distinguish cases collected after the June wave, and interacted it with the "Clinton primary voter" variable. As expected, results reveal that 
Clinton voters were significantly more likely to support Obama after June than they were before. $^{7}$

The McCain model, presented in Table 2, depicts a contrasting electoral narrative. Data show no significant early effects of supporting one of his key rivals (Huckabee or Romney) in the primary but that factor increased McCain's favorability in June $(b=.25)$ and September $(b=$ .25), after controlling for effect of Republican partisanship and the earlier favorability score. Candidate impressions appear to have crystallized by the October measurement, resulting in insignificant coefficients in both models. Since both models include a lagged dependent variable, the insignificant coefficient suggests that favorability scores were not changing for these groups as election day approached. ${ }^{8}$

\section{[INSERT TABLES 1 AND 2 ABOUT HERE]}

Ultimately, voting is about choices among or between competing electoral options. Voters do not generally express a simple like or dislike for one candidate but consider each candidate relative to others. They employ comparative candidate evaluations (Rahn, Krosnick, and Breuning 1990; Rahn et al. 1994). As such, Figure 3 charts the net difference between Obama and McCain favorability scores over the course of the primary and general election seasons. Higher scores reflect greater support for Obama; lower scores reflect greater support for McCain. Once again, data reveal dramatic differences between the two parties. First, note the initial relative position of Obama and McCain among Clinton voters, which reflects no significant difference between the likeability of Barack Obama and John McCain (.09). While assessments of the Democratic nominee improve somewhat over time, they do not rise to the

\footnotetext{
${ }^{7}$ Results are available from the authors upon request.

${ }^{8}$ This finding echoes researchers who have argued that shifts in voter judgments near election day are largely "near random" reactions to "mixed message" information flows rather than a reflection of real changes in opinion (Gopoian and Hadjiharalambous 1994; Nir and Druckman 2007).
} 
levels of relative support expressed by Obama supporters or Democrats overall. Those who voted for McCain's primary rivals (Huckabee and Romney), however, already prefer McCain to Obama by a substantial degree in January (-1.11). By June, this group expressed higher favorability scores for McCain (-2.2) than Republicans in general (2.1). In September, Huckabee-Romney voters were more favorable toward McCain than those who supported his nomination bid (2.95 versus 2.7$)$.

\section{[INSERT FIGURE 3 ABOUT HERE]}

Longitudinal trends in Figure 3 reveal the clear contrast between a unified party (Republicans) and a party marked by disunity (Democrats) in 2008. In particular, we track how much improvement candidates made with various sub-groupings of primary voters, including partisans and those who voted for key rivals, and thereby foreshadow the level of potential party unity or defection to come in November. Over the course of the entire campaign, John McCain was able to improve his differential scores among Huckabee/Romney voters from 1.11 in January to 2.81 in October - a total of 1.70 points. Obama was able to move Hillary voters by a slightly smaller amount, from .08 to 1.68 - a total of 1.6 points. This late surge toward Obama represents a remarkable .52 improvement from September to October. Clinton voters reached a net favorable high for Obama in October but Huckabee/Romney voters had far surpassed that level of net favorable for McCain by June (-2.11). The practical result would be a dramatically less unified Democratic party going into the general election vote, with less time available for Obama to close the gap.

Table 3 presents the results from regression models predicting candidate favorability differential between Obama and McCain for the five panel wave data points. Interestingly, negative coefficients for Clinton voters in January $(b=-1.14)$ and February $(b=-.65)$ indicate 
that they were actually more favorable toward McCain when considered relative to Obama. Also, echoing the candidate-specific findings, Huckabee/Romney voters were more positive about the Republican nominee when considered alongside the Democrat in June $(b=-.51)$ and September $(b=-.68)$. The larger adjusted R2 values, ranging from .21 to .80 , indicate superior model fit.

\section{[INSERT TABLE 3 ABOUT HERE]}

Analyses of self-reported general election votes further illuminate the challenges Obama faced in unifying Democrats and former supporters of his key rival. Table 4 provides a breakdown of candidate preferences and turnout among those who supported opponents of the eventual party nominee. Most importantly, three times more Clinton primary voters crossed party lines to vote for McCain in November than Huckabee/Romney voters who defected to Obama (19 percent versus 5 percent). We find no initial support for the turnout hypothesis since a roughly equivalent number from both sides stayed home on Election Day. Nonetheless, these numbers reinforce the stark general electoral picture for Obama, as Clinton voters were more prone to support his opponent, crossing party lines in the process.

\section{[INSERT TABLE 4 ABOUT HERE]}

We further clarify individual-level electoral dynamics with a pair of multinomial logit (MNL) regression models which estimate the 2008 presidential vote with a three-way outcome: vote for Obama, vote for McCain, and did not vote. ${ }^{9}$ Key independent variables include those that represent primary election vote preference and conventional, political, and demographic controls are also included. ${ }^{10}$ Results are presented in Table 5.

\section{[INSERT TABLE 5 ABOUT HERE]}

\footnotetext{
${ }^{9}$ Similar MNL modeling techniques have been employed by Bélanger et al. (2006), Gold (2002) and Green and Harris (2007).

${ }^{10}$ See Appendix for variable definitions.
} 
Note that MNL coefficients are properly interpreted in terms of relative effects. Since the reference category in Model A is "not voting" in the 2008 General Election, positive coefficients indicate that respondents are more likely to vote for Obama or vote for McCain as compared to not voting. Results show that being a Clinton primary supporter did not make one significantly more likely to vote for Obama, as opposed to abstaining on Election Day $(b=.33)$. Selfidentified partisan Democrats are more likely to turn out and vote Obama $(b=2.10)$. These findings support the turnout hypothesis. Being a Clinton supporter did not improve a respondent's likelihood of voting on election day. In contrast, Huckabee/Romney primary supporters are more likely to vote for McCain than not voting $(b=1.42)$ as are Republicans $(b=$ $1.83)$.

Model B tests the head-to-head contest between the two party nominees whereby positive coefficients indicate a greater likelihood of voting for McCain as compared to voting for Obama. Findings reveal that being a Clinton voter does not significantly improve the chances of supporting her former Democratic rival. Being a Huckabee/Romney primary voter, however, significantly increases the likelihood of supporting McCain $(b=1.45)$. Results for self-identified partisans are as expected. Republicans are more likely to vote for McCain $(b=1.87)$ and Democrats are more likely to vote for Obama $(b=-2.0)$. These findings support the hypothesis that, in November 2008, the Republicans behaved as an electorally unified party while Democrats were still hindered by the primary battle.

\section{Conclusion}

Several years ago, Holbrook (1994) highlighted a significant gap in the literature on electoral behavior. "Every four years the U.S. public goes through the ritual of a presidential election campaign. For all of the drama and attention afforded these campaigns, little is known 
about the dynamics of public opinion during a campaign season" (973). Wlezien and Erikson (2002, 969-70) also noted how "scholars are only beginning to understand the evolution of election sentiment over time.”

The 2008 Democratic nomination contest presents an opportunity to trace shifting public attitudes during a single election year and, in doing so, to test the notion that extended presidential primary processes harm nominees in the general election. Findings presented in this article suggest that prolonged presidential primaries create problems for a party's nominee in the general election. Clinton primary voters only began moving their support Obama well into the summer, after the prolonged nomination campaign ended. This was roughly three months after supporters of McCain's key primary rivals began the process of coalescing around the Republican nominee. Clinton supporters were not particularly likely to turn out in the general election, and those who did vote were not necessarily inclined to vote for the Democratic nominee. It is apparent that lower levels of support for Obama among Clinton voters reflected the damage produced from the prolonged campaign effort, and effectively prevented the Democratic Party from fully uniting around their nominee in the general election. Had Obama been given more time to unify the party, he may have been able to continue the trend of improving favorability among Clinton primary voters and enjoyed the electoral benefits on Election Day in November.

There is still much to learn about the consequences of prolonged presidential primary elections. Beyond the immediate electoral implications, it is possible that they could produce other more long-term consequences. Some observers have questioned whether the "Obama versus Clinton" intra-party contest would spill into the next presidential election cycle (Newport 2010; Rothman 2010). An extended nomination battle may also impact upon a newly elected 
president's honeymoon period, the amount of policy support a president receives over the course of his administration, and other issues related to the president's role in democratic governance. A protracted primary contest may also cultivate more motivated, registered partisans in more states, strengthening party organizations and benefiting that party in the general election campaign (Associated Press 2008).

The analyses in this study also suggest that states moving their primary dates forward may have an impact beyond increasing a particular state's influence on the selection of nominees. Front-loading, by shortening the primary campaign season, may help political parties consolidate support for the nominee in advance of the convention. How parties manage the timing of the presidential nomination process, it seems, can have implications for who wins in November. 


\section{Appendix}

\section{Variables and Descriptions}

Obama Favorability is a seven-point like-dislike scale, with 1 being "dislike a great deal" and 7 being "like a great deal".

McCain Favorability is a seven-point like-dislike scale, with 1 being "dislike a great deal" and 7 being "like a great deal".

Favorability $_{\mathrm{T}-1}$ represents the respondent's score on a seven-point like-dislike scale, with 1 being "dislike a great deal" and 7 being "like a great deal," in the previous panel wave.

Clinton Voter is a dichotomous (0-1) measure that represents self-reported voting for Hillary Clinton in the primaries.

Huckabee/ Romney Voter is a dichotomous (0-1) measure that represents self-reported voting for either Mike Huckabee or Mitt Romney in the primaries.

Age represents self-reported age on general election day.

Democrat is a dichotomous (0-1) measure that represents self-reported affiliation with the Democratic Party at wave 10.

Republican is a dichotomous (0-1) measure that represents self-reported affiliation with the Republican Party at wave 10.

Female is a dichotomous (0-1) measure that represents being a female.

Ideology is a seven-point ideology scale, with 1 being "extremely liberal" and 7 being "extremely conservative" as self-reported at wave 10 .

Education is a five-point education level scale, with 1 being no high school diploma and 5 being graduate degree. 
Figure 1. Obama Favorability, January through October

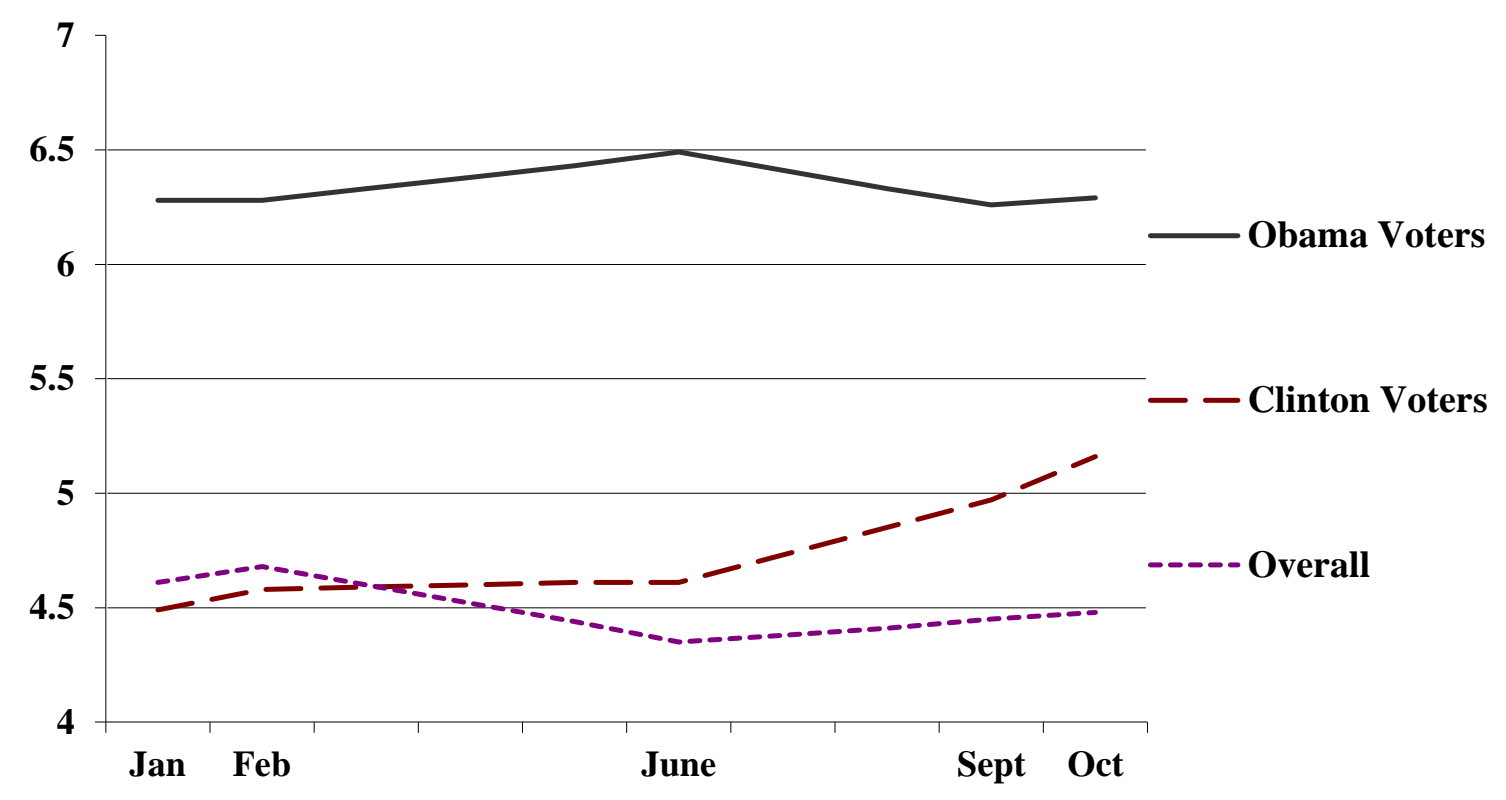

Figure 2. McCain Favorability, January through October

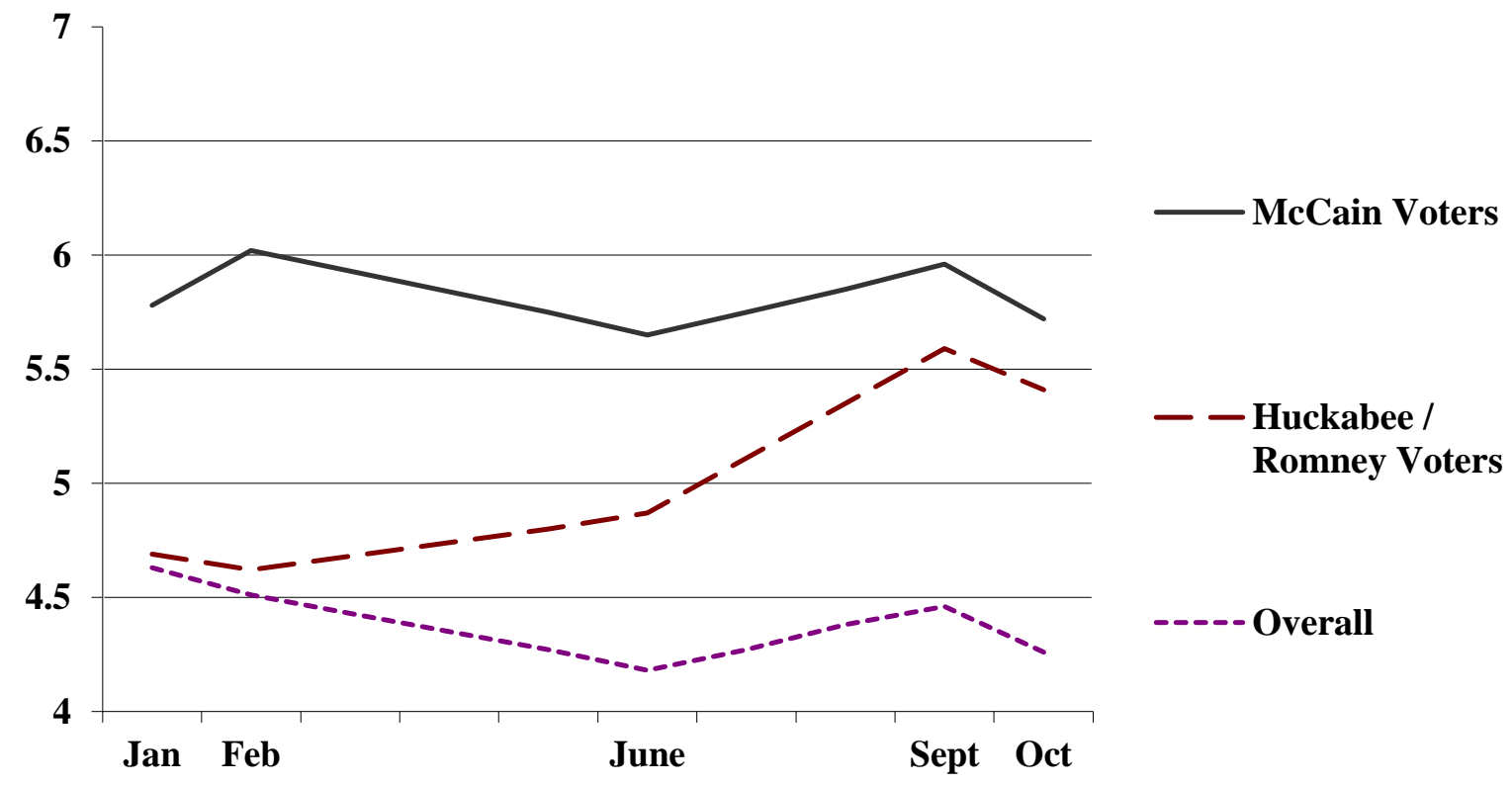

Notes: Lines in above tables represent average favorability scores on a seven-point scale (with 1 being "dislike a great deal" and 7 being "like a great deal"). Data are collected during the five panel wave months with other points imputed in order to preserve scale. 


\section{Table 1. Predicting Obama Favorability}

\begin{tabular}{llllll} 
Independent Variables & January & February & June & September & October \\
\hline \hline \multirow{2}{*}{ Constant } & & & & & \\
& $4.04^{* * *}$ & $1.40^{* * *}$ & $.63 * * *$ & $.83 * * *$ & $.73 * * *$ \\
Obama Favorability $\mathrm{T}-1$ & $(.06)$ & $(.07)$ & $(.11)$ & $(.08)$ & $(.07)$ \\
& -- & $.69 * * *$ & $.70^{* * *}$ & $.79 * * *$ & $.77 * * *$ \\
Democrat & & $(.02)$ & $(.02)$ & $(.02)$ & $(.02)$ \\
& $1.55^{* * *}$ & $.59^{* * *}$ & $1.06^{* * *}$ & $.45^{* * *}$ & $.67 * * *$ \\
Clinton Voter & $(.10)$ & $(.07)$ & $(.09)$ & $(.08)$ & $(.08)$ \\
& $-1.06^{* * *}$ & $-.51^{* * *}$ & -.21 & .15 & -.12 \\
& $(.15)$ & $(.10)$ & $(.12)$ & $(.10)$ & $(.09)$ \\
Adjusted R2 & & & & & .76 \\
(N) & .14 & .61 & .58 & .70 & 1150
\end{tabular}

Table 2. Predicting McCain Favorability

\begin{tabular}{|c|c|c|c|c|c|}
\hline Independent Variables & January & February & June & September & October \\
\hline Constant & $\begin{array}{l}4.15 * * * \\
(.50)\end{array}$ & $\begin{array}{l}1.49 * * * \\
(.10)\end{array}$ & $\begin{array}{l}1.12 * * * \\
(.11)\end{array}$ & $\begin{array}{l}1.21 * * * \\
(.10)\end{array}$ & $\begin{array}{l}.98 * * * \\
(.08)\end{array}$ \\
\hline McCain Favorability ${ }_{\mathrm{T}-1}$ & -- & $\begin{array}{l}.60 * * * \\
(.02)\end{array}$ & $\begin{array}{l}.59 * * * \\
(.02)\end{array}$ & $\begin{array}{l}.68 * * * \\
(.03)\end{array}$ & $\begin{array}{l}.67 * * * \\
(.02)\end{array}$ \\
\hline Republican & $\begin{array}{l}.99 * * * \\
(.09)\end{array}$ & $\begin{array}{l}.54 * * * \\
(.08)\end{array}$ & $\begin{array}{l}.95^{* * * *} \\
(.08)\end{array}$ & $\begin{array}{l}.77 * * * \\
(.09)\end{array}$ & $\begin{array}{l}.71 * * * \\
(.08)\end{array}$ \\
\hline Huckabee /Romney Voter & $\begin{array}{l}-.28 \\
(.15)\end{array}$ & $\begin{array}{l}-.09 \\
(.12)\end{array}$ & $\begin{array}{l}.25^{*} \\
(.12)\end{array}$ & $\begin{array}{l}.44 * * \\
(.13)\end{array}$ & $\begin{array}{l}-.10 \\
(.12)\end{array}$ \\
\hline $\begin{array}{l}\text { Adjusted R2 } \\
\text { (N) }\end{array}$ & $\begin{array}{l}.08 \\
1386\end{array}$ & $\begin{array}{l}.43 \\
1378\end{array}$ & $\begin{array}{l}.46 \\
1296\end{array}$ & $\begin{array}{l}.56 \\
1169\end{array}$ & $\begin{array}{l}.64 \\
1143\end{array}$ \\
\hline
\end{tabular}

Notes: Cell entries in the above tables are OLS regression coefficients. Standard errors are in parentheses. "Favorability ${ }_{\mathrm{T}-1}$ " represents the favorability score provided for the candidate in the previous panel wave.

$* \mathrm{p}=.05, * * \mathrm{p}=.01, * * * \mathrm{p}=.001$ 


\section{Figure 3. Obama - McCain Favorability Differential, January Through October}

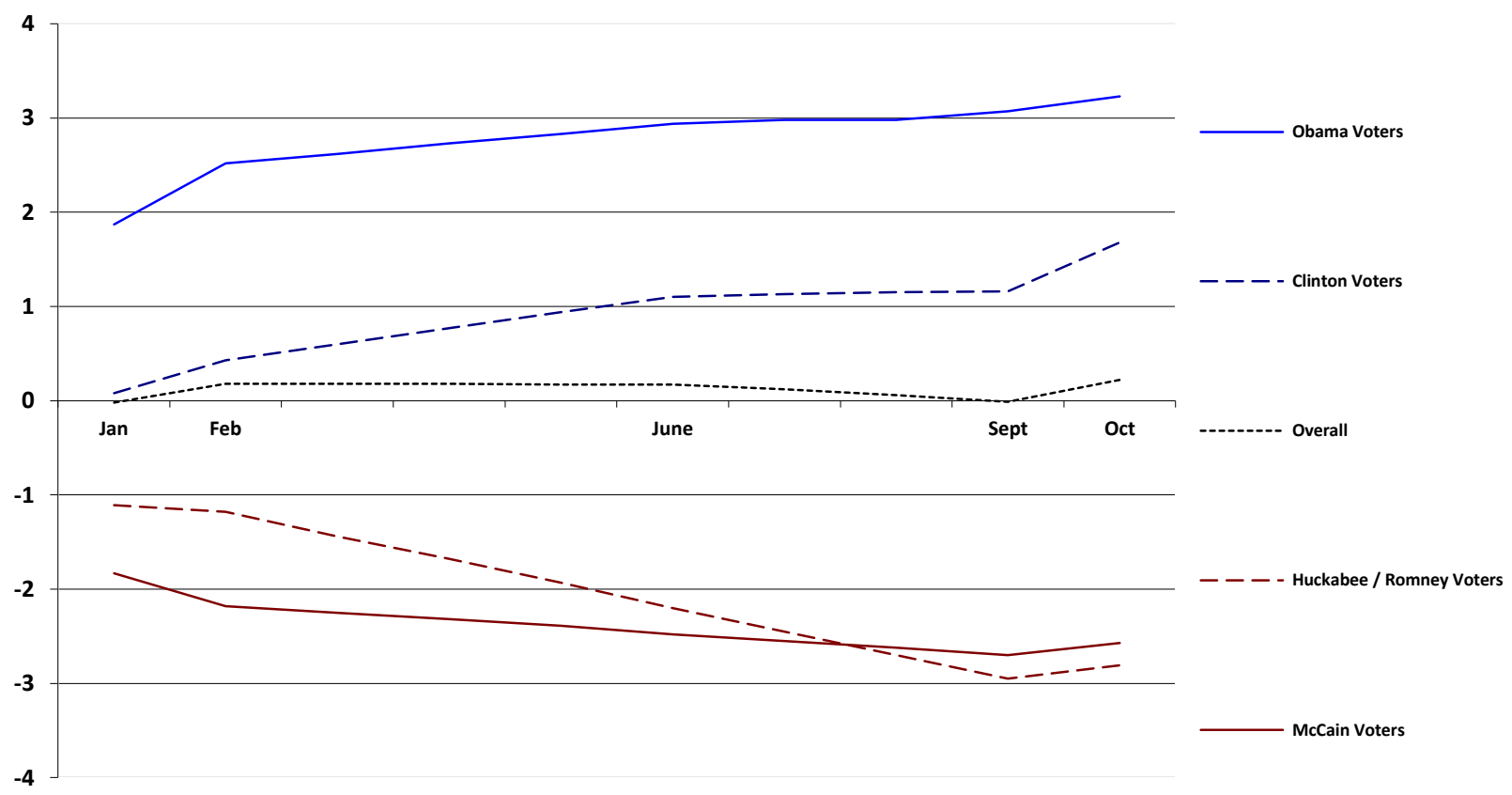

Notes: Lines represent average candidate favorability differential scores (Obama minus McCain) on a seven-point scale (with 1 being "dislike a great deal" and 7 being "like a great deal"). Data are collected during the five panel wave months with other points imputed in order to preserve scale.

\section{Table 3. Predicting Candidate Favorability Differential (Obama - McCain)}

\begin{tabular}{|c|c|c|c|c|c|}
\hline Independent Variable & January & February & June & September & October \\
\hline Constant & $\begin{array}{l}.19 \\
(.11)\end{array}$ & $\begin{array}{l}.37 * * * \\
(.09)\end{array}$ & $\begin{array}{l}-.09 * * * \\
(.10)\end{array}$ & $\begin{array}{l}.14 * * * \\
(.11)\end{array}$ & $\begin{array}{l}.28 * * * \\
(.11)\end{array}$ \\
\hline Obama - McCain ${ }_{\mathrm{T}-1}$ & -- & $\begin{array}{l}.69 * * * \\
(.02)\end{array}$ & $\begin{array}{l}.65 * * * \\
(.02)\end{array}$ & $\begin{array}{l}.84 * * * \\
(.02)\end{array}$ & $\begin{array}{l}.77 * * * \\
(.02)\end{array}$ \\
\hline Republican & $\begin{array}{l}-1.43 * * * \\
(.15)\end{array}$ & $\begin{array}{l}-.65^{* * *} \\
(.13)\end{array}$ & $\begin{array}{l}-.99 * * * \\
(.14)\end{array}$ & $\begin{array}{l}-.74 * * * \\
(.14)\end{array}$ & $\begin{array}{l}-.75 * * * \\
(.14)\end{array}$ \\
\hline Huckabee / Romney Voter & $\begin{array}{l}-.19 \\
(.22)\end{array}$ & $\begin{array}{l}-.18 \\
(.18)\end{array}$ & $\begin{array}{l}-.51^{*} \\
(.19)\end{array}$ & $\begin{array}{l}-.68 * * * \\
(.18)\end{array}$ & $\begin{array}{l}-.03 \\
(.16)\end{array}$ \\
\hline Democrat & $\begin{array}{l}1.30 * * * \\
(.15)\end{array}$ & $\begin{array}{l}.73 * * * \\
(.13)\end{array}$ & $\begin{array}{l}1.29 * * * \\
(.14)\end{array}$ & $\begin{array}{l}.24 \\
(.15)\end{array}$ & $\begin{array}{l}.53 * * * \\
(.14)\end{array}$ \\
\hline Clinton Voter & $\begin{array}{l}-1.14 * * * \\
(.19)\end{array}$ & $\begin{array}{l}-.65 * * * \\
(.15)\end{array}$ & $\begin{array}{l}-.18 \\
(.17)\end{array}$ & $\begin{array}{l}-.11 \\
(.16)\end{array}$ & $\begin{array}{l}-.09 \\
(.14)\end{array}$ \\
\hline $\begin{array}{l}\text { Adjusted R2 } \\
\text { (N) }\end{array}$ & $\begin{array}{l}.21 \\
1381\end{array}$ & $\begin{array}{l}.57 \\
1371\end{array}$ & $\begin{array}{l}.63 \\
1255\end{array}$ & $\begin{array}{l}.73 \\
1167\end{array}$ & $\begin{array}{l}.80 \\
1148\end{array}$ \\
\hline
\end{tabular}

Notes: Cell entries are OLS regression coefficients. Standard errors are in parentheses. "Obama-McCain T-1" represents the candidate favorability differential score provided in the previous panel wave. $* \mathrm{p}=.05, * * \mathrm{p}=.01$, $* * * \mathrm{p}=.001$ 
Table 4. General Election Preference and Turnout,Among Supporters of Primary Opponents

\begin{tabular}{lll} 
General Election Vote & Clinton Voters & Huckabee / Romney Voters \\
\hline \hline For Obama & $74 \%$ & $5 \%$ \\
For McCain & $19 \%$ & $89 \%$ \\
Did not vote & $7 \%$ & $6 \%$ \\
(N) & 206 & 135 \\
\hline
\end{tabular}

Cell entries represent the percentage of voters in each category. 
Table 5. Multinomial Logit Estimates of 2008 General Election Vote

\begin{tabular}{|c|c|c|c|}
\hline \multirow[b]{2}{*}{ Independent Variable } & \multicolumn{2}{|c|}{ Model A: Did Not Vote } & \multirow{2}{*}{$\begin{array}{l}\text { Model B: Vote Obama } \\
\text { Vote McCain }\end{array}$} \\
\hline & Vote Obama & Vote McCain & \\
\hline \multirow[t]{2}{*}{ Constant } & -.55 & .85 & 1.40 \\
\hline & $(.87)$ & $(.81)$ & $(.84)$ \\
\hline \multirow[t]{2}{*}{ Age } & $.02 * * *$ & $.04 * * *$ & $.01 *$ \\
\hline & $(.01)$ & $(.01)$ & $(.01)$ \\
\hline \multirow[t]{2}{*}{ Female } & .09 & .12 & .03 \\
\hline & $(.19)$ & $(.19)$ & $(.19)$ \\
\hline \multirow[t]{2}{*}{ Education } & $.56^{* * *}$ & $.20 *$ & $-.36 * * *$ \\
\hline & $(.09)$ & $(.09)$ & $(.09)$ \\
\hline \multirow[t]{2}{*}{ Income } & .03 & .03 & .01 \\
\hline & $(.02)$ & $(.02)$ & $(.03)$ \\
\hline \multirow[t]{2}{*}{ White } & -.04 & $.87 * * *$ & $.91 * * *$ \\
\hline & $(.21)$ & $(.24)$ & $(.24)$ \\
\hline \multirow[t]{2}{*}{ Democrat } & $2.10 * * *$ & .17 & $-2.0 * * *$ \\
\hline & $(.23)$ & $(.27)$ & $(.26)$ \\
\hline \multirow[t]{2}{*}{ Republican } & -.04 & $1.83 * * *$ & $1.87 * * *$ \\
\hline & $(.32)$ & $(.26)$ & $(.31)$ \\
\hline \multirow{2}{*}{ Ideology } & $-.14 * * *$ & .09 & $.23 * * *$ \\
\hline & $(.02)$ & $(.81)$ & $(.05)$ \\
\hline \multirow{2}{*}{ Clinton Voter } & .33 & .58 & .25 \\
\hline & $(.29)$ & $(.34)$ & $(.27)$ \\
\hline \multirow[t]{2}{*}{ Huckabee/Romney Voter } & .03 & $1.42 * *$ & $1.45^{* *}$ \\
\hline & .60 & .46 & .50 \\
\hline Log pseudo likelihood & 2540.1 & & 2540.1 \\
\hline Pseudo R2 (Nagelkerke) & .60 & & .60 \\
\hline$(\mathrm{N})$ & 1206 & & 1206 \\
\hline
\end{tabular}

Notes: Entries are unstandardized multinomial logit regression coefficients. "Did not vote in the 2008 General Election" serves as the reference category for Model A. "General Election vote for Obama" serves as the reference for Model B. Standard errors are in parentheses. 


\section{References}

ADAmS, JAmes, and SAMUEl MerriLl III. 2003. "Voter Turnout Strategies in American Elections." Journal of Politics 65 (1): 161-189.

ASSOCIATED PRESS. 2008. "DEMOCRATS Post BIg Gains IN Voter REGISTRATION." ASSOCIATED PRESS. ACCESSED ON JUNE 24, 2011. AVAILABLE ONLINE AT HTTP://WWW.MSNBC.MSN.COM/ID/26575403/NS/POLITICS-DECISION_08/

AtKeSON, LONNA. 1998. "Divisive Primaries and General Election Outcomes: Another Look at Presidential Campaigns.” American Journal of Political Science 42 (1): 256-271.

BARTEls, LARRY. 1999. "Panel Effects in the American National Election Studies." Political Analysis 8 (1): $1-20$.

BÉlAnger, Éric, Michael S. LEWIS-Beck, JEAn CHICHE, and VinCENT TIBERJ. 2006. "Party Ideology, and Vote Intentions: Dynamics from the 2002 French Electoral Panel." Political Research Quarterly 59 (4): 503-515.

Brody, Richard, and Benjamin PAge. 1973. "Indifference, Alienation, and Rational Decisions: The Effects of Candidate Evaluation on Turnout and the Vote." Public Choice 15 (Summer): 1-17.

BURDEN, BARRY C. 2009. "The Nominations: Rules, Strategies, and Uncertainty." In The Elections of 2008, edited by Michael Nelson. Washington, DC: CQ Press.

CNN. 2008. "Clinton wins key primaries, CNN projects; McCain clinches nod." Accessed on June 24, 2011. Available online http://www.cnn.com/2008/POLITICS/03/04/march.4.contests/index.html

EZRA, MARNI. 2001. "The Benefits and Burdens of Congressional Primary Elections." In Congressional Primaries and the Politics of Representations, edited by Peter F. Galderisi, Marni Ezra, and Michael Lyons. Lanham, MD: Rowman and Littlefield. 48-61.

Glaser, James M. 2005. The Hand of the Past in Contemporary Southern Politics. New Haven, CT: Yale University Press.

GOLD, HOwARD. 2002. "Third-Party Voting in Gubernatorial Elections: A Study of Angus King Of Maine and Jesse Ventura of Minnesota." Polity 35 (2): 265-282.

Gopoian, J. DAVID, and Sissie HadjIHARALAMBous. 1994. "LATE-DECIDING Voters IN PRESIDENTIAL ELECTIONS." POLITICAL BEHAVIOR 16(1): 55-78.

Green, Matthew, and Douglas Harris. 2007. "Goal Salience and the 2006 Race for House Majority Leader." Political Research Quarterly 69 (4): 618-630.

Grofman, Bernard. 2004. "Downs and Two-Party Convergence." Annual Review of Political Science 7: $25-46$.

HACKER, ANDREW. 1965. "Does a Divisive Primary Harm a Candidate's Election Chances?" American Political Science Review 59 (1): 105-10.

Henderson, Michael, D. Sunshine Hillygus, and Trevor Tompson. 2010. "Sour Grapes or Rational Voting? Voter Decision Making Among Thwarted Primary Voters in 2008." Public Opinion Quarterly 74 (3): 1-31.

HiLlygus, D. Sunshine. 2007. "The Dynamics of Voter Decision Making Among Minor Party Supporters: The 2000 U.S. Presidential Election.” British Journal of Political Science 37 (2): 225-244. 
Holbrook, Thomas. 1994. "Campaigns, National Conditions, and U.S. Presidential Elections" American Journal of Political Science 38(4): 973-998.

JaCKMAN, SimOn and LYNN VAVReCK. 2010. "Primary Politics: Race, Gender, and Age in the 2008 Democratic Primary." Journal of Elections, Public Opinion, and Policy 20 (2): 153-186.

JACOBSON, GARY C. 2010. "George W. Bush, the Iraq War, and the Election of Barack Obama." Presidential Studies Quarterly 40(2): 207-224.

Jesse, StePhen A. 2010. "Voter Ideology and Candidate Positioning in the 2008 Presidential Election." American Politics Research 38 (2): 195-210.

KenNEY, PATRICK and TOM RICE. 1984. "The Effect of Primary Divisiveness in Gubernatorial and Senatorial Elections." Journal of Politics 46 (3): 904-15.

. 1987. "The Relationship between Divisive Primaries and General Election Outcomes." American Journal of Political Science 31 (1): 31-44.

KRISTOF, NichOlAS. 2008. "Obama, Clinton and Echoes of Nader." New York Times. Accessed on June 24, 2011. Available online at http://www.nytimes.com/2008/03/27/opinion/27kristof.html

LAZARUS, JEFFREY. 2005. "Unintended Consequences: Anticipation of General Election Outcomes and Primary Election Divisiveness." Legislative Studies Quarterly 30 (3): 435-462.

LENGLE, JAMES. 1980. "Divisive Presidential Primaries and Party Electoral Prospects, 1932-1976." American Politics Quarterly 8 (3): 261-77.

Lengle, James, Diana Owen, and Molly Sonner. 1995. "Divisive Nominating Mechanisms and Democratic Party Electoral Prospects.” Journal of Politics 57 (2): 370-83.

Lewis-Beck, Michael S., Charles Tien, and Richard NADEAU. 2010. "Obama's Missed Landslide: A Racial Cost?" PS: Political Science and Politics 43 (1): 69-76.

Mayer, William, and ANDrew Busch. 2003. The Front-Loading Problem in Presidential Nominations. Washington, DC: Brookings Institution Press.

Miller, WARREN. 1999. “Temporal Order and Causal Inference.” Political Analysis 8 (2): 119-146.

NEWPORT, FrANK. 2008. "Democratic Groups Most at Risk of Deserting." Gallup. Accessed on June 24, 2011. Available online at http://www.gallup.com/poll/105742/democratic-groups-most-riskdeserting.aspx

. 2010. "Obama 52\%, Clinton 37\% for 2012 Democratic Nomination." Gallup. Accessed on June 24, 2011. Available online at http://www.gallup.com/poll/143318/obama-clinton-2012democratic-nomination.aspx

NiR, LILACH, and JAMES N. DRUCKMAN. 2007. "Campaign Mixed Message Flows and Timing of Vote Decisions." International Journal of Public Opinion Research 20 (3): 326-346.

NORRANDER, BARbARA. 1986. "Selective Participation: Presidential Primary Voters as a Subset of General Election Voters." American Politics Quarterly 14 (1): 35-53.

Piston, SPencer. 2010. "How Explicit Racial Prejudice Hurt Obama in the 2008 Election." Political Behavior 32 (4): 431-451.

RAHN, Wendy, Jon A. Krosnick, and MARIJKe BReUning. 1994. "Rationalization and Derivation Processes in Survey Studies of Political Candidate Evaluation." American Journal of Political Science 38 (3): 582-600. 
RAHn, Wendy, John Aldrich, Eugene BorgidA, and John Sullivan. 1990. "A Social Cognitive Model of Candidate Appraisal." In Information and Democratic Process, edited by John Ferejohn and James Kuklinski. Chicago, IL: University of Chicago Press.

Rothman, NoAH. 2010. "Poll Suggests a Primary Challenge to Obama in 2012 may be in the Cards." Campaigns and Elections. Accessed on June 24, 2011. Available online at http://www.campaignsandelections.com/campaign-insider/Poll-Suggests-a-Primary-Challenge-toObama-in-2012-may-be-in-the-Cards

SOUTHWEll, Priscilla L. 2010. "The Effect of Nomination Divisiveness on the 2008 Presidential Election.” PS: Political Science and Politics 43 (2): 255-258.

Stone, Walter J., and L. SAndy Maisel. 2003. "The Not-So-Simple Calculus of Winning: Potential U.S. House Candidates' Nomination and General Election Prospects." Journal of Politics 65 (4): 951-977.

Sussman, Dalia. 2010. "Poll: Obama-Clinton Divide." New York Times. Accessed on June 24, 2011. Available online at http://thecaucus.blogs.nytimes.com/2008/04/30/poll-obama-clinton-divide/

Tumulty, Karen. 2009. "What Does Hillary Want?" Time. Accessed on June 24, 2011. Available online at http://www.time.com/time/politics/article/0,8599,1808470,00.html

Winneg, KenNeth, and KathleEn Hall Jamieson. 2010. "Party Identification in the 2008 Presidential Election.” Presidential Studies Quarterly 40 (2): 247-263.

Wlezien, Christopher and ROBERT ERIKSON. 2002. "The Timeline of Presidential Election Campaigns." Journal of Politics 64(4): 960-993. 